\title{
Democracy and Democratic Education: Searches and Concerns
}

\author{
Sousanna-Maria Nikolaou (Corresponding author) \\ Associate Professor \\ Department of Primary \\ Education, University of Ioannina, Greece \\ E-mail: snikola@cc.uoi.gr \\ Monika A. Papa \\ Phd, Teaching Staff, Athens School of Fine Arts, \\ Athens, Greece \\ E-mail:monikapapa@gmail.com \\ Charalambos Barbarousis \\ PhD Candidate \\ Department of Primary Education \\ University of Ioannina \\ E-mail: chmparbarousis@gmail.com
}

Received: Oct. 30, 2019 Accepted: Dec. 30, 2019 Published: Feb. 27, 2020

doi:10.5296/ijssr.v8i1.16563 URL: http://dx.doi.org/10.5296/ijssr.v8i1.16563

\begin{abstract}
The main axis of this study includes the analysis of democracy as a political system and as a social mechanism and way of life, the reflection on the crisis of democracy today and the causes of its challenge, as well as the definition of democratic education as a determining factor in shaping the democratic citizen with active citizenship.

Democracy as a political system in modern industrial societies became popular because of its
\end{abstract}




\section{Macrothink \\ International Journal of Social Science Research \\ ISSN 2327-5510 \\ 2020, Vol. 8, No. 1}

association with the socio-economic system and the dissemination of democratic ways of living people by the media. all over the world. The globalization of social life with the possibility of expanding and legitimizing democracy initially gave the impression that the establishment of a stable democratic order in a country as an undertaking is not difficult. However, through a historical review of the evolution of the globalization of the economy, which has brought considerable benefits to the production and accumulation of wealth, the system's inability to ensure the quality and efficiency of democratic institutions is featured (Alexander, Thompson \& Edles, 2016; The Economist Intelligence Unit's Democracy Index 2016). Democracy is being called into question today. This is because in countries with high economic growth, where formal procedures seem to maintain democratic processes, there is a lack of prosperity and social equality for all sections of the population, a deepening of social inequalities, a sharp contraction of the middle class.

Because democracy is not only a form of government but, above all, a way of communicating, interacting with people in pursuit of a common interest, it offers multiple possibilities for action. Therefore, it shows the role of democratic citizens in order to thrive and preserve democracy. And the formation of a democratic citizen is achieved in democratic schools that promote democratic processes and enhance the development of democratic conscience and behavior in the new man. In the project we present proposals and practices for shaping the democratic active citizen through democratic education.

Keywords: Democracy, democratic education, theories, concerns, suggestions 


\section{Introduction}

Humans are born as biological beings (biophysical beings) and with the cognitive ability that characterizes them (their ability to learn), they become social, political beings with spiritual dimension (Henecka, 1980; Muehlbauer, n.d.; Giddens, 2002; Tzani, 1998). The capacity for both political and civilized behavior is determined by the degree of access to citizenship. The social status that defines citizenship includes individual rights (right to ownership, right to freedom of expression, etc.), civil rights (the right to vote and stand as a candidate) and social rights that refer to the right of access to a satisfactory standard of living (Marshall \& Bottomore, 2001). So, no citizen is born, but rather becomes one. When man becomes a social being in a society with a well-defined organization, power has a collective and political dimension and derives its power and is enforced on the basis of formal rules and statutory mechanisms (e.g. by voting). The formal organization of social power, that is, political power, is understood as the state. Moreover, the establishment of some basic social decision-making mechanisms for the distribution of intellectual and material goods is a prerequisite for the existence of any society (Easton, 1971: 135).

It is true that power (Note 1) is concentrated in the states and monopolized by them; however, from the above meaning according to Easton, it works with positive consequences for the social system. Therefore, power must be supported and reinforced to serve the common interest, as it possesses collective and distributive functions that challenge the public engagement of the policy audience, i.e. the public (Parsons, 1960: 220-221). In political sociology, the concept of the public is not precisely defined. It can be understood in the sense of the crowd or the mass, where it mainly refers to forms of collectivity that are distinguished by a sense of laxity, but also by the sense of citizens or members of a political community (Price, 1996). The public, as citizens of a political social group acquires significant power in a democracy where power is legalized and exercised by the people or its elected representatives, the politicians. Politicians, as public servants, must exhibit integrity, honesty and responsibility, and from their position seek to protect the public from the greed of businesses. When these are financed and act on the basis of financial interests of private interests, then democracy and the independence of the citizens are threatened (Alexander, Thompson, \& Edles, 2016: 701-702).

\section{Questioning Democracy}

Democracy is defined as the most dynamic idea of the 20th century, since even the remaining semi-feudal monarchies in the context of globalization are influenced by many democratic trends. The simplest meaning of the term "democracy" includes the notion of a system that distinguishes itself for the effective competition between different political parties for the occupation of power (Giddens, 2002: 114 et seq.). But how is democracy defined in a society that is complex both in terms of the system of governance and in the heterogeneity of populations and cultures? According to Lipset (1981: 27, 1994: 3-5) democracy is on the one hand a political system that allows citizens (the public) opportunities under the Constitution established by the political community to change the rulers and on the other hand, a social mechanism that provides the opportunity for the greater part of society through the political 
rights it has, to influence major decisions through the choice of different positions of conflicting groups operating in the political community. Therefore, for democracy to function, the necessary prerequisites are (a) one or more social groups that hope and struggle through noble emulation to rise to power, alternating in power, (b) a set of political leadership in power and of course in the social context, (c) the acceptance and functioning of values related to the way of governance, the functioning of political parties, freedom of speech and of the press. For a democracy to thrive and stabilize, it requires a high level of socio-economic development, measured by indicators not only of wealth or industrialization but also of the level of education and education of the population, and the value system which supports equality of citizens and their participation in political organizations. Social stratification is clearly accepted, but according to Lipset (1959: 71), class structure must be relatively open to a large and growing middle class. The strong position of the middle class acts as a balancer for democratic legitimacy and the promotion of democratic values vis-à-vis the arbitrariness of the higher classes when it comes to redistributing wealth (Aranitou, 2011: 159-173).

Democracy as a political system in modern industrial societies has become popular because of its association with the socio-economic system and the spread of democratic lifestyles by the media all over the world. The globalization of social life with the possibility of extending and legitimizing democracy (in most states through free elections) initially gave the impression that establishing a stable democratic order in a country is not a difficult task. However, a historical overview of the evolution of globalization of the economy that has brought significant benefits to the production and accumulation of wealth, reveals the inability of the system to guarantee the quality and effectiveness of democratic institutions (Giddens, 2002; Alexander, Thompson, \& Edles, 2016).

Democracy is being called into question today. This is because in countries with high economic growth, where the democratic processes at formal level seem to be maintained, there is a lack of prosperity and social equality for all sections of the population, a deepening of social inequalities, a sharp decline in the middle class. And it becomes dangerous when these conditions are observed in countries that have born or established democracy for years. In the literature, one can see the scientific debate on the crisis of legitimizing democracy through the democratic deficit regarding erosion and alienation of collective values, the decline of political participation, the lack of trade union mobility, the reduction of confidence in the political system, public policy tools and public institutions as well as the gap between the aspirations of the citizens of a favored democracy and the existing reality (Aranitou, 2011; Schmidt, 2004; Mavrozacharakis, 2015; Crouch, 2006; The Economist Intelligence Unit's Democracy Index, 2016). A clear picture of the democratic deficit is "the increasing number of instances of the weakening of the principle of the legitimacy of the action of the state institutions [...] and the constantly declining course of the democratic legitimization of this action" (President of the Hellenic Republic Prokopis Pavlopoulos, 2018).

Today's society is reminiscent of a set of connected societies with loose relationships and dependencies that lack a substratum of a society of shared thought and action, mainly due to the heterogeneity of different groups of the population. However, society is perceived by nature as one (Dewey, 1966). The gradual acceptance of multiculturalism, which can result 
from social interaction, which eliminates the distances between different groups by allowing for acquaintance, enlargement and acceptance, also implies challenging the sovereignty of any individual national culture and civilization. Every social interaction between different groups causes a continuous adjustment of the conditions that correspond to the new situations that are created. Because democracy is not only a form of governance, but mainly a way of communicating, interacting with those pursuing a common interest, it gives multiple opportunities for action and liberation of a variety of personal competences (Dewey, 1966). Therefore, the importance of democratic citizens for the prosperity and preservation of democracy is clearly visible. And democratic citizenship is achieved in democratic schools that promote democratic processes.

\section{The Contribution of Democratic Education}

Studying the literature and research on democratic schools shows that the preparation of democratic citizens is based on the teaching of democratic processes in the school environment with key features of democratic leadership, the discernment of important knowledge about the social and political development of young people and the democratically oriented environment for adapting to the resulting social changes and participating in a common interest (Dewey, 1966; Nikolaou, 2018; Schulz et al., 2010; Schulz, Ainley, \& Fraillon, 2013; Alivernini \& Manganelli, 2011: 3441-3445; Torney-Purta, Wilkenfeld, \& Barber, 2008: 857-880; Gould, 2011). Democratic processes in the classroom presuppose appropriate teaching models based on dialogue and collective decision-making on the issues under consideration. In particular, the following are considered necessary: (a) the cooperation and interaction of those involved in the learning process; (b) respect for and acceptance of one's view / position; (c) exemption from prejudice related to the phenomenon of self-fulfilling prophecies (Pygmalion) and students' individual restrictions (due to the socio-economic status of family, race, gender, language and accent etc.) (Brookover et al., 1996; Nikolaou, 2018).

According to research (Mosher, Kenny, \& Garrod, 1994), civic engagement of young adolescents is influenced and reinforced by the prevailing conditions in the classroom and at school in general. One of the main goals of education, in order to ensure system consistency, is to smoothly integrate young people into society by socializing the core values and attitudes of society (Kelpanidis, 2012; Konstantinou, 2015; Nikolaou, 2009). The classroom debate and dialogue that are developed in the classroom on cognitive, social, political or cultural issues and are governed by the freedom to express standpoints and opinions, actually shape political attitudes related to citizen participation. That is, students understand the quality of the active citizen who participates in the community, acquire strong role models of active, responsible and democratic citizenship, develop positive attitudes towards the rights of immigrants or minority groups, and have a greater sense of political effectiveness. In short, the school governed by democratic principles also promotes the learning of democratic principles in general, and thus the formation of active, participatory democratic citizens (Hahn, 1999).

Moreover, citizen participation in social activities requires inclusive education and 
participatory practices in schools. Democratic education is considered essential in national education systems in the form of the introduction of democracy into school systems through experiential learning of democratic practices and by including democratic education in teacher training. The convergence of democracy and education is appropriate, as democracy is taught not only as a theory but also as a way of life, and education, as a public institution, plays a decisive role in the development of a democratic society (Nussbaum, 2010: cap. V)

What citizen, then, do we seek to shape through democratic education? Active Citizens who have developed social and communication skills think critically, analyze, decide correctly on social issues, evaluate alternatives and set new goals. And this can be achieved because democracy and education cultivate common values, such as solidarity, cooperation, mutual respect, dialogue, objective knowledge and critical creative thinking. Active citizenship that interests and engages in public affairs is developed and cultivated on a daily basis in a social interaction framework that exerts critical thinking by evaluating historical sources and critically analyzing economic principles, promoting respect for the future, seeking creativity and innovative solutions, developing effective strategies in a value-free environment with adult support and ongoing feedback (Nussbaum, 2010: 176 cap. VI; Freire, 2006: 253 et c.). In both European and national contexts, initiatives for the protection and prosperity of democracy are taking place.

In particular, within Europe, the establishment of the European Community of Democratic Education (EUDEC) supports democratic processes in communities that promote learning with the ultimate aim of shaping active, educated citizens for a modern democratic society. Democratic education is based on self-regulated learning inside and outside the classroom (independent study, online research, museum visits, volunteering, talking with friends and teachers) and in the learning community within a framework of democratic principles such as equality, mutual respect, solidarity, tolerance for diversity through the development of social relationships and interactions (http://www.eudec.org).

The program "Democracy and Education" was designed and implemented in a national context, by the Educational Programs Department of the Hellenic Parliament Foundation. The program is aimed at teachers who are interested and concerned about the democratic education of their students, supporting innovative actions and initiatives in schools, participation in cultural and group programs, environmental programs, health education programs or the creation of projects in the teaching of principles and values of democracy, political education and parliamentary and political history (Hellenic Parliament Foundation, Educational Programs, "Democracy and Education").

\section{Conclusion}

Taking into account the conclusions of the World Forum for Democracy and Equality (Strasbourg 7-9 November 2016), the actions and activities of the European Community regarding Democratic Education (EUDEC) on citizenship and human rights and education rights (Strasbourg, 20-22 June 2017, http://idec2016.org/), as well as the efforts made at national level (programs such as 'Democracy and Education') are found to be inextricably linked to the extension and legalization of democracy with education (and as a result of 
Humanity and Enlightenment) in order to achieve the development (social, economic) that will bring prosperity to all social strata.

It is therefore appropriate for democratic education to take a formal, institutional form in national education systems, both in the form of teacher education and the introduction of democracy in school systems (democratic processes, democratic governance in schools and participatory democracy for the students). Democratic education builds on the experience of democracy in practice and the engagement of students, teachers and parents. Citizen participation in social activities arises as a result of social competence in an interactive environment characterized by participatory practices and fostering democratic skills (Zins, Weissbert, Wang \& Walberg, 2004; Nikolaou, 2018). With such practices we contribute to the formation of democratic citizens with critical thinking and analysis skills, citizens with social skills (interpersonal, survival, problem solving and social acceptance) (Chandler, Lubeck, \& Fowler, 1992), critical for positive social interaction, citizens able to evaluate social situations, and "set new goals that will not focus on self-interest or market economy but on human dignity and democratic dialogue" (Nikolaou, 2018: 89). A strong democracy rests on rationality and imagination (Nussbaum, 2010: cap. epilogue).

\section{References}

Alexander, J. C., Thompson, K., \& Edles, L. D. (2016). A contemporary Introduction to Sociology: Culture and Society in Transition. Rouledge Taylor and Francis Group. https://doi.org/10.4324/9781315636429

Alivernini, F., \& Manganelli, S. (2011). Is there a relationship between openness in classroom discussion and students' knowledge in civic and citizenship education? Procedia Social and Behavioral Sciences, 15, 3441-3445. https://doi.org/10.1016/j.sbspro.2011.04.315

Aranitou, B. (2011). Oso perissotero enimeri mia chora, toso megalyteri einai i pithanotita na diatirithei se aftin i dimokratia. I epikairotita mias analytikis paratirisis. Epistimi kai Koinonia: Epitheorisi Politikis kai Ethikis Theorias, 27, 159-173.

Brookover, W. B., Erickson, F. J., \& McEvoy, A. W. (1996). Creating effective schools: An in-service program for enhancing school learning climate and achievement. Holmes Beach, FL: Learning Publications.

Chandler, L. K., Lubeck, R. C., \& Fowler, S. A. (1992). Generalization and maintenance of preschool children's social skills: a critical review and analysis. Journal of Applied Behavior Analysis, 25(2), 415-428. https://doi.org/10.1901/jaba.1992.25-415

Crouch, C. (2006). Metademocracy. Athina: Ekkremes (in Greek).

Demertzis, N. (1990). Ousiodes amfisvitisimotita kai theories peri exousias. Theoria kai Koinonia, 3, 23-46. (in Greek).

Dewey, J. (1966). Democracy and Education. An Introduction to the Philosophy of Education. Toronto, Ontario: Copyright Macmillan Company 1916.

Easton, D. (1971). The Political System: An Inquiry into the State of Political Science. New 


\section{Macrothink}

York: Alferd Knopf.

Economist Intelligence Unit. (2017). Democracy Index 2016 - Revenge of the "Deplorables". [online] p. Economist Intelligence Unit. Retrieved September 17, 2019, from https://www.eiu.com/public/topical_report.aspx?campaignid=DemocracyIndex2016

Freire, P. (2006 [1998]). Teachers as Cultural Workers. Letters to Those Who Dare Teach. Westview Press, A member of the Perseus Books Group, (in Greek)

Giddens, A. (2002). Sociology. Athina: Gutenberg. (in Greek)

Gould, J. (ed.). (2011). Guardian of Democracy: The Civic Mission of Schools. The Leonore Annenberg Institute for Civics of the Annenberg Public Policy Center at the University of Pennsylvania and the Campaign for the Civic Mission of Schools. Retrieved from http://www.civicmissionofschools.org

Hahn, C. L. (1999), Citizenship Education: An empirical study of policy, practices and outcomes, Oxford Review of Education, 25(1-2), 231-250.

Hellenic Parliament Foundation, Educational Programs, "Democracy and Education". https://doi.org/10.12968/sece.2018.12.11

Henecka, H. P. (1980). Grundkurs Erziehungssoziologie. Verlag Herder Freiburg im Breisgau.

Kelpanidis, M. (2012). Koinoniologia tis ekpaideysis. Theories kai Pragmatikotita. Thessaloniki: Zygos.

Konstantinou, C. (2015). To kalo sxoleio, o ikanos ekpaideytikos kai i katallili agogi os paidagogiki theoria kai praxi. Athina: Gutenberg.

Lipset, S. M. (1959). Some Social Requisites for Democracy: Economic Development and Political Legitimacy, The American Political Science Review, 53(1), 69-105. https://doi.org/10.2307/1951731

Lipset, S. M. (1981 [1960]). Political Man: The Social Bases of Politics. Baltimore: John Hopkins University Press

Lipset, S. M. (1994). The social requisites of Democracy. American Sociological Review, 59(1), 1-22. https://doi.org/10.2307/2096130

Marshall, T. H., \& Bottomore, T. (2001). Citizenship and social class. Athnina: Gutenberg. (in Greek).

Mavrozacharakis, E. (2015). About Political Legitimation and the Deepening of Democracy. https://doi.org/10.2139/ssrn.2686279

Mosher, R., Kenny, R. A., \& Garrod, A. (1994). Preparing for citizenship: Teaching youth to live democratically. Westport, CT: Praeger.

Muehlbauer, K. R. (n.d.). Sozialisation. Eine Einführung und Theorien und Modelle. 
Thessaloniki: Kyriakidis (in Greek).

Nikolaou, S.-M. (2009). Koinonikopoiisi sto sxoleio. Athina: Gutenberg.

Nikolaou, S.-M. (2018). Koinoniologikes symvoles sti diamorfosi toy energou dimokratikou politi, $\sigma \tau$ o. In S.-M. Nikolaou, T. Elefterakis, E. kalerante, P. Giavrimis \& G. Koustourakis (Eds), Nees prokliseis stin ekpaideysi kai ti demokratia (pp. 82-108). Athina: Gutenberg.

Nussbaum, M. (2010). Not for profit: Why democracy needs the humanities. Princeton University Press.

Parsons, T. (1960). Structure and Process in Modern Societies. Glencoe IL: Free Press.

President of the Hellenic Republic P. Pavlopoulos. (2018). The Rule of Law Crisis as a Crisis of Democratic Legalization of Leadership. Speech at the HARVARD University Center for Greek Studies on "Leadership and Humanitarian Values", in Nafplio. Available at: IDEAS \& CONSIDERATIONS, APE - MPE (in Greek).

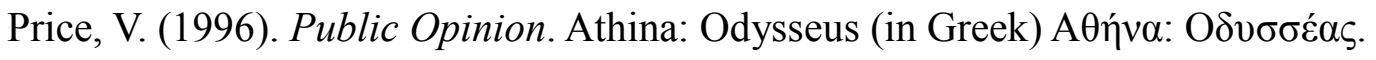

Schmidt, M. (2004). Theories of Democracy. Athina: Savalas (in Greek.

Schulz, W., Ainley, J., \& Fraillon, J. (2013). Student participation at school and future civic engagement: Results from ICCS 2009. Paper prepared for the 5th IEA International Research Conference in Singapore, 26-28 June 2013. Retrieved from http://www.iea.nl/fileadmin/user_upload/IRC/IRC_2013/Papers/IRC-2013_Schulz_etal.pdf

Schulz W., Ainley J., Fraillon J., Kerr, D., \& Losito, B. (2010). ICCS 2009 International Report: Civic knowledge, attitudes, and engagement among lower secondary school students in 38 countries. Amsterdam, The Netherlands: International Association for the Evaluation of Educational Achievement (IEA).

Torney-Purta, J., Wilkenfeld, B., \& Barber, C. (2008). How Adolescents in 27 Countries Understand, Support, and Practice Human Rights. Journal of Social Issues, 64(4), 857-880. https://doi.org/10.1111/j.1540-4560.2008.00592.x

Tzani, M. (2004). Koinoniologia Paideias. Athina: Grigori.

Zins, J. E., Weissberg, R. P., Wang, M. C., \& Walberg, H. J. (Eds.). (2004). Building academic success on social and emotional learning: What does the research say? New York, NY, US: Teachers College Press.

\section{Notes}

Note 1. Cf. An attempt to record and describe common reference points of the most well-known theories of power, In: N. Demertzis (1990). Ousiodes amfisvitisimotita kai theories peri exousias, Theoria kai Koinonia 3, Dec. Athina: Gnosi, pp. 23-46. 


\section{Copyrights}

Copyright for this article is retained by the author(s), with first publication rights granted to the journal.

This is an open-access article distributed under the terms and conditions of the Creative Commons Attribution license (http://creativecommons.org/licenses/by/4.0/). 